\%

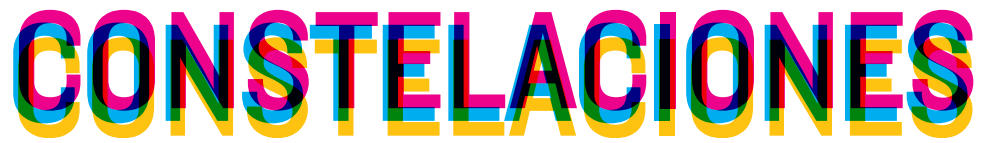

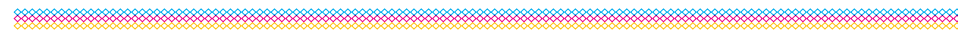


CONSTELACIONES nํㅜ, mayo 2015

Revista de Arquitectura de la Universidad CEU San Pablo

Architecture Magazine of CEU San Pablo University

Periodicidad anual

Annual periodicity

COMITÉ DE REDACCIÓN EDITORIAL COMMITTEE

Dirección Direction

Juan García Millán

Santiago de Molina

Jefa de Redacción Editor in Chief

Covadonga Lorenzo Cueva

Secretario de Redacción Editorial Clerk

Rodrigo Núñez Carrasco

Maquetación y producción Design and production

María Fernández Hernández

Vocales Board Members

Juan Manuel Ros. Escuela Politécnica Superior, Universidad CEU San Pablo, Madrid

Diego Cano Pintos. Escuela Politécnica Superior, Universidad CEU San Pablo, Madrid

Juan Arana Giralt. Escuela Politécnica Superior, Universidad CEU San Pablo, Madrid

Maribel Heredia Castilla. Escuela Politécnica Superior, Universidad CEU San Pablo, Madrid

\section{CONSEJO EDITORIAL EDITORIAL BOARD}

Beatriz Colomina. School of Architecture, Princeton University, New Jersey

Carmen Díez Medina. Escuela de Ingeniería y Arquitectura, Universidad de Zaragoza

María Antonia Frías Sargadoy. Escuela Técnica Superior de Arquitectura, Universidad de Navarra

Juan Miguel Hernández Léon. Escuela Técnica Superior de Arquitectura, Universidad Politécnica de Madrid

Juan José Lahuerta Alsina. Escuela Técnica Superior de Arquitectura, Universidad Politécnica de Cataluña, Barcelona

Eduardo Leira Sánchez. Ex director del Plan General de Ordenación Urbana, Madrid

Joaquín Medina Wamburg. Facultad de Aquitectura Diseño y Urbanismo, Universidad de Buenos Aires

Zaida Muxí Martínez. Escuela Técnica Superior de Arquitectura, Universidad Politécnica de Cataluña, Barcelona

José Joaquín Parra Bañón. Escuela Técnica Superior de Arquitectura, Universidad de Sevilla

Víctor Pérez Escolano. Escuela Técnica Superior de Arquitectura, Universidad de Sevilla

Fernando Pérez Oyarzún. Escuela de Arquitectura y Diseño, Pontificia Universidad Católica, Santiago de Chile

Judith Sheine. School of Architecture and Allied Arts, University of Oregon, Portland

Andrés Walliser Martínez. Global Design, New York University, Nueva York

\section{ISSN 2340-177X}

Depósito legal M-13872-2013

(c) de los textos, sus autores

(c) de las imágenes autorizadas

(c) Revista Constelaciones

๑) Escuela Politécnica Superior, Universidad CEU San Pablo

Universidad CEU San Pablo

Escuela Politécnica Superior

Urbanización Montepríncipe, $s / n$

Boadilla del Monte, 28668. Madrid (España)

constelaciones@eps.ceu.es

www.uspceu.es

Edición Edition

Fundación Universitaria San Pablo CEU

Madrid, España

Impresión Printing

VA Impresores

Impreso en España Printed in Spain

Distribución Distribution

CEU Ediciones

Los textos que componen Constelaciones se obtienen mediante convocatoria pública. Para que los trabajos recibidos entren en el proceso de selección de los artículos a publicar deben ser trabajos originales no publicados anteriormene, con una extensión recomendada de 3.000 palabras, título, resumen (un máximo de 150 palabras) y palabras clave (un mínimo de cuatro palabras), en español y en inglés. Tras haber cumplido estos requisitos (y los correspondientes incluidos en las normas editoriales de la revista, disponibles para consulta en formato digital desde el comienzo de la convocatoria), tiene lugar un proceso de revisión y evaluación de los artículos previa aceptación de los mismos para su publicación. Para acometer dicho proceso, y con el fin de asegurar la calidad de los contenidos, la Revista Constelaciones recurre a evaluadores externos a la institución editora y anónimos (cada artículo es evaluado por dos de ellos) encargados de someter a crítica los mismos. Todos los artículos de investigación publicados en esta revista han pasado por dicho proceso. La recepción de artículos se extendió hasta el 30 de septiembre de 2014. Texts included in Constelaciones are obtained by public announcement. Only original papers that have not been previously published will be included in the process of selection of articles. They should not exceed 3.000 words and should include a title, an abstract (no more than 150 words) and keywords (a minimum of four words), in Spanish and English. After having fulfilled these requirements (and those included in magazine editorial standards, available for consultation from the beginning of the Call for Papers), occurs a process of review and evaluation of articles upon acceptance of them for publication. To undertake this process, and in order to ensure the quality of the contents, Constelaciones turns to external and anonymous evaluators to the institution (each article is evaluated by two of them) responsible for the critic. All the articles published in this journal have undergone this process. The deadline for reception was extended until September 30, 2014.

Todos los derechos reservados. Esta publicación no puede ser reproducida, ni en todo ni en parte, ni registrada, ni transmitida, ni almacenada en ninguna forma ni por ningún medio, sin la autorización previa y por escrito del equipo editorial. En este número se han utilizado algunas imágenes de las que no se ha podido identificar al propietario de los derechos. En estos casos hemos entendido que las imágenes son de libre uso. En caso de identificar alguna de estas imágenes como propia, por favor, póngase en contacto con la redacción de Constelaciones. Los criterios expuestos en los diversos artículos de la revista son responsabilidad exclusiva de sus autores y no reflejan necesariamente los que pueda tener el equipo editoral. El equipo editorial de la revista no se responsabiliza de devolver la información enviada a la redacción a no ser que se le solicite expresamente. All rights reserved. This publication cannot be reproduced, in whole or in part, nor registered, transmitted or stored in any form or by any means, without the written permission of the Editorial team, In this issue some images were used without knowing the owner of the rights. In these cases, we have understood that the images are free of use. In case you identify shared by the editors of this journal. The publisher don't take responsibility for returning submitted material which is not expressly requested. 


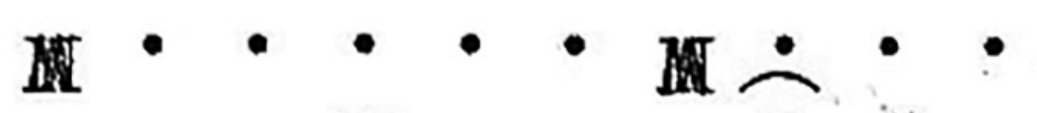

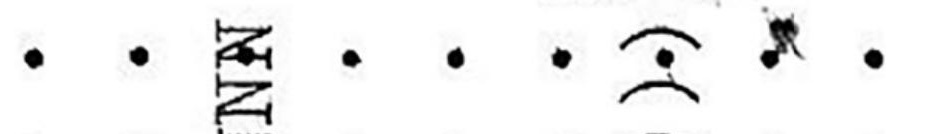

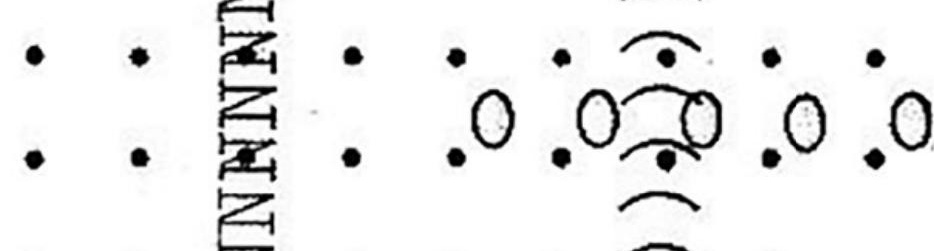

- 0 否 000 a 00

- 0 爱 000 全 00

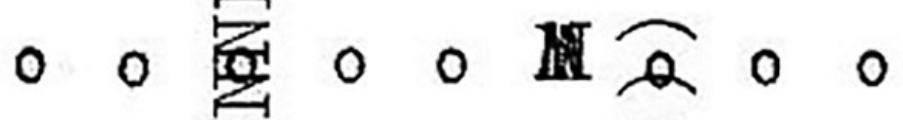

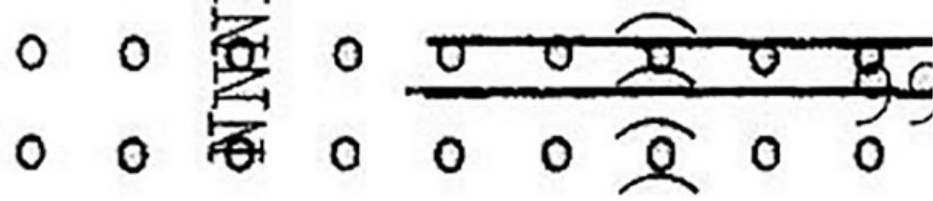

$0 \quad 0 \quad 0 \quad 0 \quad 0 \quad 0$ 2 00

$0 \therefore \therefore \bar{\sigma} 0$ O $0^{\circ}$

$\begin{array}{lllllllll}0 & 0 & 0 & 0 & 0 & 0 & 0 & 0 & 0\end{array}$

M 0 - 0 - 0 - 0 月。

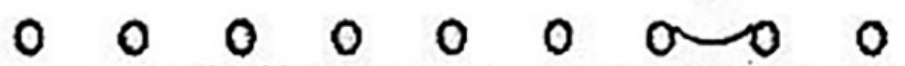

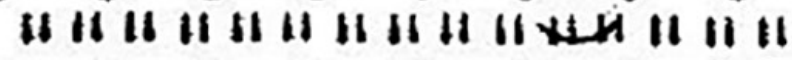

- 0 0 0 o 0 a 00

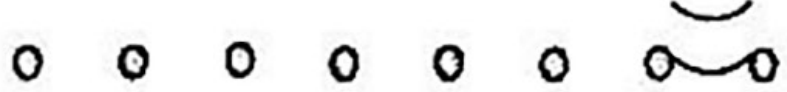

0

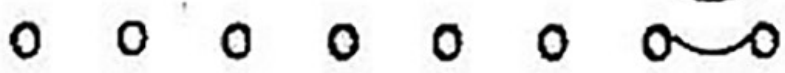

0

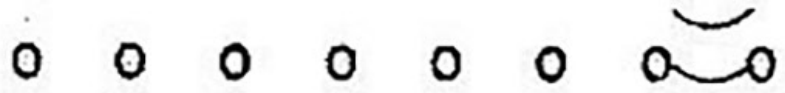

0

政 0 - 0 o 


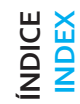

$\hat{m}$

in

요

$\infty$

ֻ̊ำ

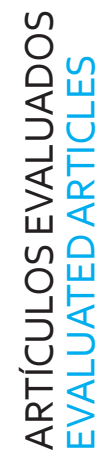
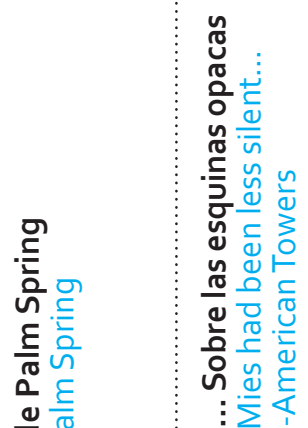

음

o

눈

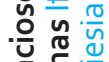

동

要

흥

प⿺辶寸

合 है

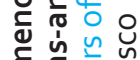

당

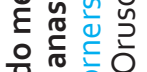

$\sum_{0}$

중

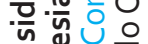

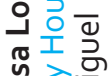

品

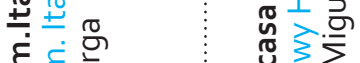

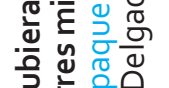

उ.

응

N

๗ั

ज该

ㅂ.

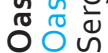

든흥응

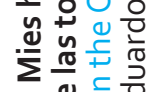

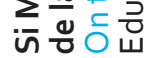

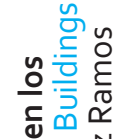

엉 N

른 은

닌

흐 호

는

的㐫

흥

>둥

ํํㅁ 맘

ס)

ปั $\frac{0}{0}$

ชั่ $3 \frac{1}{2}$

ฮ

-

언 $\frac{0}{3} \frac{0}{\pi}$

온

룽

ช

은 을

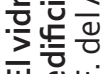

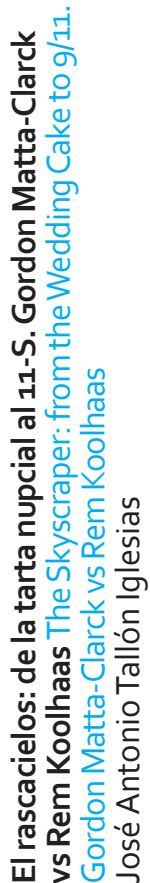

등 응

(

든 $\frac{0}{\pi}$

은 은

-

๘

究

ง

ดั อิ

은

은 ํำ

은 븡

ชั

ติ

든 인

는

ชర

므Nㅗㅇ

드음 궁

으 으 은

c) $\frac{1}{\sigma}$

듬

믄 응

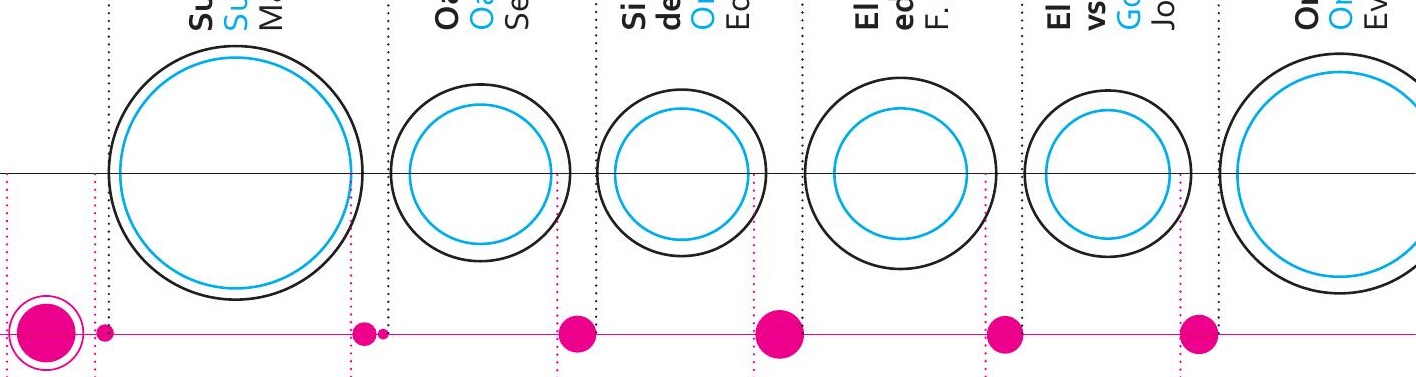

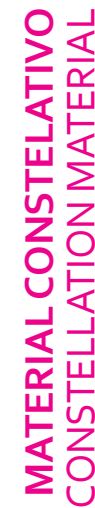

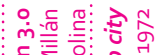

:ํㅡㄴ

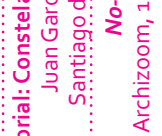

뜸

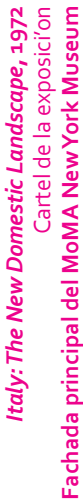

นิ้

앙를

등 ㅎํㅇ

点

융

讨

tูำ

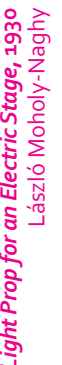

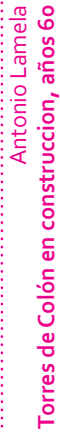

$\underline{\underline{z}} \underline{\underline{a}}=\frac{m}{}$

m

in

ڤ

$\infty$

؛ 


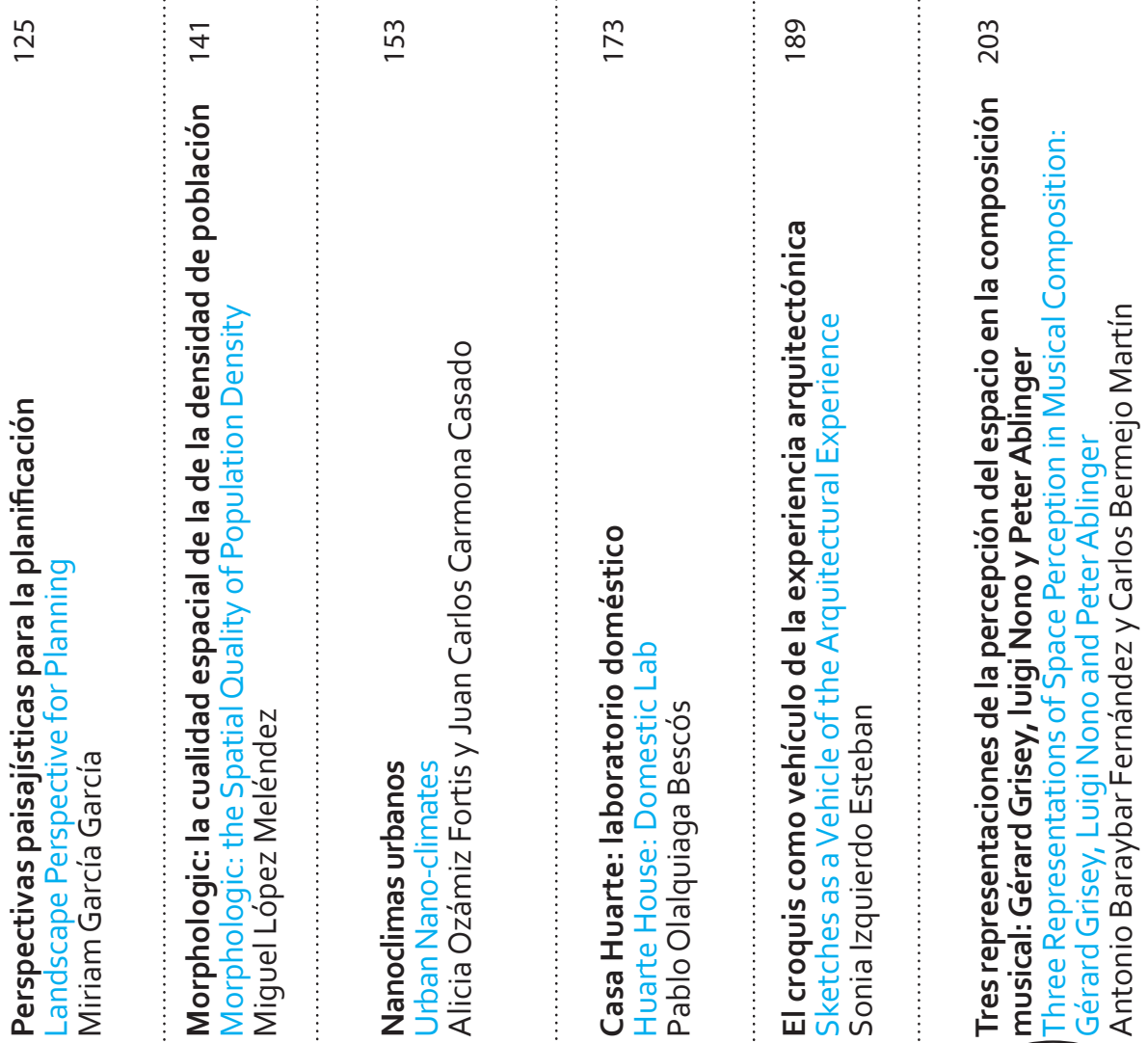




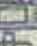

(1)

\&

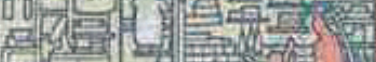
$x=$

$X$

\section{$x \rightarrow$}

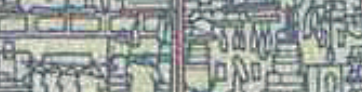

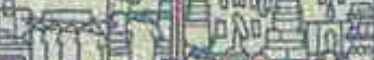

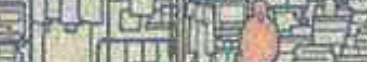

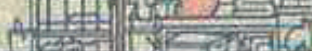

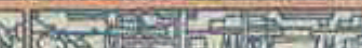

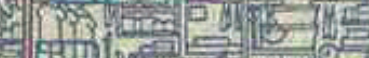

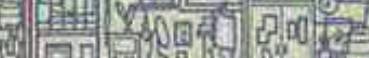

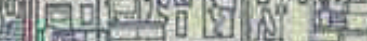
M)

(1) (n) 1)

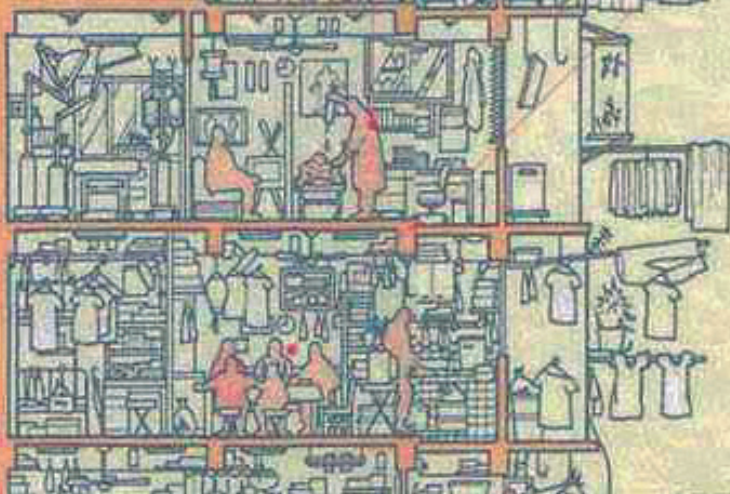

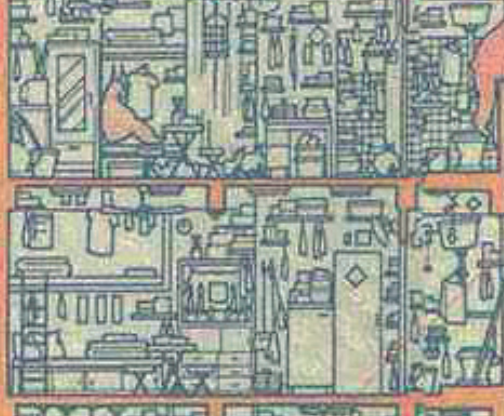
or 5 in

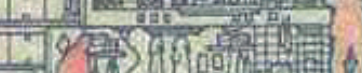

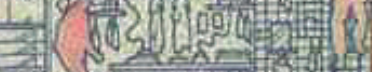

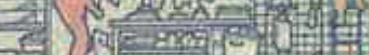
mas

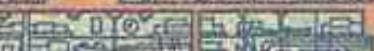
a 개

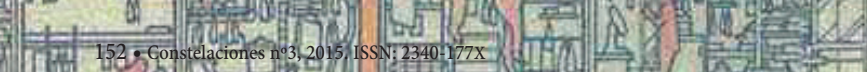
(20) ext and

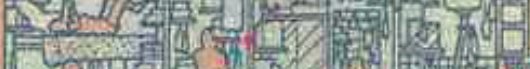

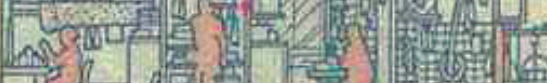

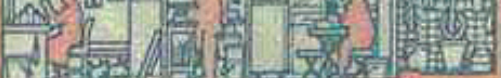

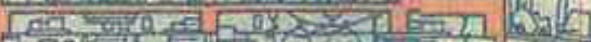

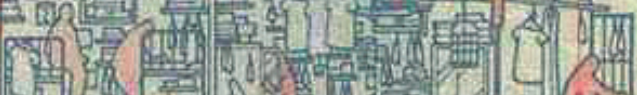
J| $551 \mathrm{~J}$

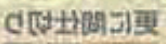

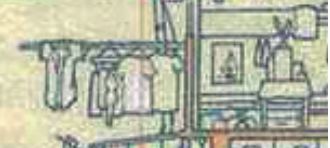

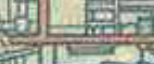
3 sitis 0. (1) M. 4. L (2) $\frac{T}{x=\ln n}$

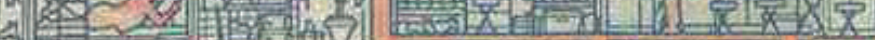

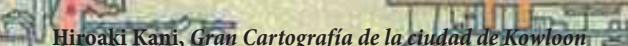
[Yos $)=$ 


\title{
Nanoclimas urbanos
}

Urban Nano-climates

\author{
Alicia Ozámiz Fortis y Juan Carlos Carmona Casado \\ Escuela de Arquitectura y Tecnología, Universidad Camilo José Cela, Madrid \\ Traducción Translation Paul Hoffmann
}

\section{Palabras clave Keywords}

Nanoclima urbano, ahorro energético, cambio normativo

Urban nano-climate, energy saving, regulatory framework

\section{Resumen}

El artículo, producto de una novedosa investigación, trata de evidenciar, mediante la toma de datos directa, la existencia de diferencias de temperatura muy significativas (hasta $6^{\circ} \mathrm{C}$ ) en un mismo entorno urbano (de no más de $5 \mathrm{~km}$ de longitud), para una misma hora de medición, en un mismo día y el mismo mes de un determinado año. También cuantifica, mediante el análisis energético de un edificio del recorrido, el ahorro producido en su acondicionamiento si se utilizara una base de datos climática más ajustada, derivada del nuevo concepto de 'nanoclima urbano'.

\section{Abstract}

As a result of innovative research, the present article attempts to show, through direct data measurements, the existence of very significant differences in temperature (up to $6^{\circ}$ Celsius) in the same urban environment, with a length not greater than five kilometers, at same measurement times, on the same day, and in the same month of a given year. It also quantifies - by means of the energy evaluation of a building on a specific itinerary - the savings produced in both thermal equipment, and the operation of the same, if a database of more accurate climate data is provided, derived from a new concept of 'urban nano-climates'. 
A pesar del creciente y reconocido interés que el estudio de la climatología urbana ha experimentado desde antiguo, (1) y de su potente y fructífero desarrollo desde finales del siglo xIX, los numerosos trabajos llevados a cabo, tanto teóricos como aplicados (sobre los 'microclimas' o sobre el fenómeno de la 'isla de calor'), han sido de índole muy general. Han abarcado áreas geográficas demasiado extensas, ya sea regionales o incluso locales (englobando multitud de situaciones y casos muy diferentes entre sí), no teniendo en cuenta, como pretende poner de manifiesto esta investigación, (2) la incidencia, en la disminución del gasto energético global urbano, de la existencia, a una escala menor, de un número amplio de diferentes climas locales específicos o 'nanoclimas', configurados por espacios mucho más reducidos (una parte de una calle, un paseo arbolado, una plaza...), y definidos por condiciones climáticas propias, con márgenes más ajustados que los que actualmente se emplean para establecer los requisitos para el diseño y construcción urbana.

De la 'isla de calor' a los 'nanoclimas urbanos'. En una primera aproximación, los estudios sobre el clima urbano se centraron, sobre todo, en la constatación de la existencia de una notable diferencia térmica entre el centro urbano y la periferia de las ciudades. Este incremento de la temperatura del aire en la ciudad respecto a la de los alrededores, especialmente de noche, se verificó por primera vez en la ciudad de Londres, a principios del siglo XIX (1818), por parte de Howard. (3) Poco después, Renou (4) detectó el calentamiento anómalo del centro de París (1868) y Schmidt lo confirmó en Viena (1930). Este fenómeno fue denominado en 1958 por el climatólogo inglés Gordon Manley, 'Urban Heat Island' (UHI), en español 'isla urbana de calor' o 'isla térmica', siendo - una vez más- Londres, la ciudad europea que más estudios ha dedicado a su 'isla de calor', gracias en parte a las contribuciones de Chandler, (5) referente obligado en este ámbito.

Hito importante fue la celebración en 1968 de un Simposio Internacional sobre climas urbanos, promovido por la Organización Meteorológica Mundial (OMM), pues se impulsaron las investigaciones de climatología urbana

Despite growing and widespread interest, since ancient times, (1) in the study of urban climates, and the powerful and fruitful development since the end of the 19th century, the numerous theoretical and applied studies carried out -especially on microclimates and heat islands- have been very general. Said studies have covered geographical areas which have been too extensive, both regional and local, (covering multiple and diverging cases) and have not taken into account -as the present study does- (2) the incidence in the decrease of world-wide urban energy expenditure, and to a lesser degree, the existence of an ample number of specific local climates or 'nano-climates' created by much smaller spaces - part of a street, a tree-shaded promenade, a square- defined by their own climate conditions, and have not taken into account the requirements, within limits which are more adjusted than those employed at present, for the establishment of urban construction and design.

From 'heat islands' to 'urban nano-climates'. In an initial approach, studies on urban climates covered, above all, the existence of notable temperature differences between urban centers and the periphery of large cities. The increase of air temperature in the city with respect to surrounding areas, especially at night, was verified for the first time in London at the beginning of the 19th century (1818) by Howard. (3) Slightly later Renou (4) detected anomalous heating in the center of Paris (1868) and Schmidt confirmed the same for Vienna (1830). This phenomenon was called 'Urban Heat Island' (UHI) in 1958 by the English climatologist Gordon Manley. Once again, more than any other European city, London has studied 'heat-islands' the most, thanks in part to the contributions of Chandler, (5) who is a reference in this field. 
de base local centradas, sobre todo, en el reconocimiento de la 'isla de calor' en distintas ciudades.

En los últimos años se han realizado estudios pioneros financiados con fondos europeos en algunas ciudades noroccidentales con el objetivo de que sus resultados se tengan en cuenta para perfeccionar la planificación urbana elaborar normas y herramientas de diseño urbano. Entre ellos cabe destacar los de las ciudades de Róterdam y Arnhem (Países Bajos), y Atenas (Grecia).

La mayor parte de las grandes ciudades de Estados Unidos y Canadá cuentan con estudios globales o parciales de clima urbano destacando, por su mayor número y profundidad, Saint Louis, Nueva York, Toronto y Montreal. En América Latina son notables los de la ciudad de Méjico, Río de Janeiro y, sobre todo, Sao Paulo.

En Japón, la ciudad de Hiroshima, por su peculiar modificación climática, y Tokio, cuentan con diversos trabajos y estudios especializados. La mayoría de ellos versan sobre los elementos del sistema urbano japonés.

Asimismo podrían citarse, sobre todo por el gran número de estudios, ciudades de África, Asia, Nueva Zelanda, etc., pero sus aportaciones no difieren mucho de las señaladas hasta ahora.

En España estos estudios climatológicos han sido muy escasos. Los investigadores del Consejo Superior de Investigaciones Científicas de Madrid (CSIC) intentaron cubrir esta laguna con una primera investigación pionera sobre la teledetección del calor captado (6) en el infrarrojo desde los aviones meteorológicos que se utilizan para este fin. Método, según la publicación a la que dio lugar, empleado por primera vez en una ciudad española.

Dicha publicación (7) -notable fuente de información- no deja de ser, sin embargo, más que el desencadenante que plantea más preguntas que respuestas para el propósito de nuestra investigación ya que, por un lado, la información

An important milestone was the celebration, in 1968, of the International Symposium on Urban Climates, organized by the World Meteorological Organization (WMO), which stimulated urban climatology research at a local level, especially centering on the admittance of 'heat-islands' in different cities.

In recent years, European funds have financed pioneer studies in some northwestern cities such as Rotterdam, Arnhem (The Netherlands) and Athens (Greece) with the idea of using the results to perfect urban planning, draw up norms and develop tools for urban design.

The majority of large cities in the United States and Canada already have global or partial studies on urban climates. Outstanding, both in number of studies and depth, are the cities of Saint Louis, New York, Toronto and Montreal. In Latin America, we can mention important studies carried out in Mexico, Rio de Janeiro and above all, Sao Paulo.

In Japan the cities of Hiroshima, with its peculiar climate changes, and Tokyo, both have diverse and specialized studies. The majority of these studies cover elements of the Japanese urban systems.

We could also mention a great number of studies carried out in cities in Africa, Asia and New Zealand, but conclusions do not differ greatly from other studies already cited. 
que proporciona es únicamente la de la banda del espectro infrarrojo y, por otro, sólo mide las emisiones de las superficies horizontales: cubiertas y azoteas, así como la de los pavimentos de las aceras y las calzadas de las calles. Lo más llamativo del exhaustivo estudio es que, a pesar de la aparente uniformidad de las cubiertas (planas, también mayoritariamente), las diferencias de calor radiante que aparecen, tanto en las fotografías en falso color como en las tablas anexas, son más que notables. Los datos que se muestran en la citada publicación del MOPT relativos a los diferentes distritos en los que se ha dividido el estudio, evidencian diferencias de temperatura de hasta seis o siete grados entre elementos urbanos prácticamente colindantes.

Además de en Madrid, (8) existen también investigaciones sobre 'islas de calor' en otras ciudades españolas tales como Barcelona, (9) Teruel, (10) Logroño, Bilbao... y, más recientemente, Alicante. (11)

Actualmente se podría afirmar, con poco margen de error, que la mayoría de las metrópolis mundiales cuentan con estudios climáticos a dos niveles de análisis: uno, inicial, con carácter meramente aproximativo y descriptivo, y otro, más reciente y de mayor profundización, en el que se analiza el clima urbano con la complejidad de sus implicaciones, climáticas y urbanísticas, a la vez que se establecen, desde distintos modelos de interpretación, relaciones explicativas generales.

En esta investigación empleamos el término 'nanoclimas' en sustitución del más habitual de 'microclimas' (12) para hacer énfasis en la diferencia de escala pues, como ya indicamos anteriormente, responde a una mayor pormenorización, no considerada hasta ahora.

Relación entre la 'isla de calor' y algunos parámetros meteorológicos y de carácter geográfico-urbano. Hasta el presente han sido numerosos los trabajos, en ciudades de todo el mundo, que han tratado de exponer las causas generadoras de la subida de temperatura en el centro urbano respecto a la periferia (subida que lleva aparejada una notable diferencia de humedad relativa en

In Spain, these studies have been very scarce. Research carried out by the CSIC (Consejo Superior de Investigaciones Cientificas - Superior Council for Scientific Research) for the city of Madrid tried to cover this void with a pioneer study on the detection, using distance infrared electronic systems from meteorological airplanes, designed to measure 'captured' heat emissions. (6) According to said study, this was the first time said method had been used for a Spanish city.

Said publication, (7) which is an important source of data, is still, nevertheless, more a cause for more questions than a provider of answers, as far as our research is concerned. On the one hand, the data obtained only covers the infrared spectrum, and, on the other hand, it only measured the horizontal surface radiation: roofs and terraces, pavements, walks and streets. Most noteworthy of this extensive study is that, despite the uniformity of the measured surfaces (mainly flat), the perceived differences in the radiating heat ( seen from badly colored photographs), are very great. Data shown in the said MOPT report (Ministry of Public works and Transport) relative to the different Madrid districts into which the study was divided, show differences of up to 6 or 7 degrees between neighbouring districts.

Besides the city of Madrid, there are also 'heat-island' studies for other Spanish cities such as Barcelona, (9) Teruel, (10) Logroño, Bilbao, and more recently, Alicante. (11)

At present we can affirm, without being too far off the mark, that most world metropolis have climate studies with two analytical levels: one merely a descriptive approximation, and the other, more recent and in greater depth, where the com- 
sentido inverso), su intensidad temporal (horaria y estacional), su distribución geográfica y efectos concretos en cada ciudad, así como la puesta en marcha de medidas para mejorar el medio ambiente en los núcleos urbanos.

Una de las causas más conocidas de la formación del fenómeno de la isla de calor' es la producción de calor antropogénico en las ciudades (sumando decisivo para obtener el balance energético de una ciudad), si bien no es la única. La radiación es otro de los componentes de dicho balance y un elemento meteorológico destacado junto con el viento, el cual afecta fundamentalmente a su intensidad y configuración. La contaminación atmosférica también es otro parámetro importante, al provocar una mayor recepción de radiación de onda larga, constituyendo, además, un serio problema en algunas grandes ciudades del mundo por la alteración física y química que provoca.

La densidad y el tamaño de los edificios en la ciudad, así como los tipos de materiales empleados en la construcción, son factores urbanos que también influyen en la 'isla térmica'. En algunos casos, como ya mostró Oke, (13) más que el tamaño de la ciudad es la compacidad urbana, sobre todo, la que permite obtener unos contrastes térmicos notables, lo que no invalida el que algunos centros comerciales que se hallen aislados puedan crear su propio efecto de 'isla de calor'.

Las áreas verdes y los parques urbanos, suponen una reducción de la temperatura de la ciudad allí donde se localizan. Además del enfriamiento del aire que conllevan, es sabido que causan también un incremento en la humedad relativa del aire y en la producción de oxígeno, así como una cierta brisa debido al aumento de su temperatura con respecto al entorno circundante, tanto al amanecer como a la caída de la tarde. A su vez, los diferentes usos del suelo también contribuyen en la formación de la 'isla de calor' y ha sido un tema muy estudiado.

Por otra parte se ha podido comprobar que las causas generadoras de este fenómeno no son lineales o continuas en el tiempo. La anomalía térmica positiva es máxima en la ciudad a las horas nocturnas, generalmente después de la puesta de sol, fruto de la irradiación. En cuanto al ritmo estacional, la

plexity of urban climates, and implications therein, are analyzed from different angles, establishing general explanations and interpretations.

In said research, the term 'nano-climate' is used instead of the more habitual 'microclimate' (12) to emphasize the difference of scale, since, as indicated above, there is a deeper and more detailed approach.

Relation between 'heat island' and some geographical, urban and climate parameters. Until the present, numerous studies in cities throughout the world have tried to set forth the reasons for temperature increases in urban centres, compared to the peripheries of the city. These differences imply an inverse relative humidity, hourly and seasonal changes, geographical distributions and specific effects for each city, leading to the adopting of measures to improve urban environments.

One of the better known causes of 'heat-islands' is anthropogenic heat production, (important criteria to be taken into account when considering a city's energy balance), but it is not the only cause. Solar radiation is another element of said balance, and must be taken into account along with wind intensity and direction. Air pollution is another important parameter which must be considered, increasing the reception of long-wave radiation, and other serious problems such as physical and chemical changes.

The building density and size, as well as materials used in edification, are urban factors which must be taken into account in 'heat-islands'. In some cases, as already shown by Oke (13), more than city size, it is the compactness of 
'isla de calor' se intensifica en invierno con situaciones de calma anticiclónica, o bien, con vientos débiles y cielos despejados o poco nubosos, aunque este fenómeno puede ser también intenso durante la época estival, como muestran estudios llevados a cabo en Ibiza (14) o en Santiago de Chile.

Referencias al método de trabajo. Son tres los parámetros fundamentales que caracterizan la 'isla de calor': su intensidad, su forma o configuración y la localización del máximo térmico.

Con frecuencia, para una primera valoración de las modificaciones urbanas, se recurre al análisis comparado con registros procedentes de los observatorios meteorológicos convencionales representativos de cada medio geográfico, pero ya que su representación cubre una escala espacial diferente, sus datos sólo pueden servir como referencia.

Es por ello que la metodología que se ha convertido en habitual, (15) y que está especialmente indicada para medir la temperatura y la humedad, es la técnica de los transectos urbanos y estaciones móviles, la cual utiliza la incorporación de automóviles donde se toman medidas meteorológicas localizadas en diversos puntos a lo largo de su recorrido. El instrumental que suele utilizarse consiste en termohigrómetros digitales, de baja inercia, con una sonda de ambiente que es la que se instala al exterior del vehículo.

El procedimiento empleado en nuestra investigación difiere del citado método pues la toma de datos se efectúa con estaciones meteorológicas portátiles, directamente a pie, sin vehículo interpuesto.

Referencias al marco normativo (internacional y nacional). En relación con la inclusión de los resultados obtenidos en las diversas investigaciones realizadas en todo el mundo en las Normativas Urbanísticas y/o Térmicas o de Eficiencia Energética, se puede concluir que las clasificaciones existentes en cuestiones de zonificación climática son muy amplias pues generalmente abarcan regiones, ciudades o municipios, y ello en el caso de las más rigurosas.

cities which give notable thermal contrasts, although some isolated shopping centers may produce their own "heatisland' effects.

Green areas and urban parks reduce city temperatures in areas where they are located. Besides cooling the air, they are known to increase relative humidity and oxygen production, and produce breezes due to the temperature differences with respect to surrounding areas, both at dawn and dusk. Different land uses also contribute to the creation of 'heat-islands', and this has also been studied extensively.

On the other hand, it has been verified that the causes of the above phenomenon are not linear or time-constant. Positive thermal anomalies are maximum in cities during the night, generally just after sundown, due to solar radiation. With respect to seasonal variations, the "heat-islands" become more intense in the winter with high pressures or weak winds, clear skies with few clouds. This phenomenon can also occur during the summer season, as seen in studies carried out in Ibiza (14) and Santiago de Chile.

Reference to working methodology. There are three basic parameters which characterize the 'heat-islands': intensity, form or configuration, and maximum thermal location.

Frequently, for an initial urban modification criteria, comparative analysis with data from other meteorological observatories are used. Said observatories cover different spatial scales, and data can only be used as a reference. 
En los Estados Unidos de América, las Normas ASHRAE (Sociedad Americana de Aire Acondicionado, Refrigeración y Calefacción), conocidas por su exigencia y rigor en materia de energía, contemplan una división climática por Estados y, dentro de ellos, una clasificación por ciudades.

En América Latina la normativa térmica de Argentina IRAM (16) del Instituto Argentino de Normalización y Certificación, que es la más relevante (en concreto, la Norma IRAM 11603 de Zonificación Bioclimática), tampoco contiene una clasificación climática rigurosa del país, aunque sí incluye consideraciones sobre 'microclimas' y una evaluación de los existentes dentro de cada zona bioambiental, diez en total, de modo muy general.

En Europa, destaca el Reglamento Térmico francés, RT-2012 que establece una clasificación en ocho zonas climáticas correspondientes a las regiones del país.

En España cabe señalar el Código Técnico de la Edificación (CTE), (17) que es el marco normativo principal que viene a plasmar en especificaciones técnicas los objetivos de la Ley de Ordenación de la Edificación (LOE) (18) y especialmente su Documentación Básica (DB) -y de Apoyo (DA) - en materia de Ahorro de Energía (HE), así como la relativa a 'climas de referencia'. Documentación Básica DB-HE (19) actualizada en 2013 para poder alcanzar, según metodología común europea, (20) unos niveles óptimos de rentabilidad y un "consumo de energía casi nulo" en todos los nuevos edificios, antes de 31 de diciembre de 2020 (2018 para los edificios públicos).

Dicha actualización, que parte de las exigencias establecidas en 2006, constituye una medida importante para el cumplimiento del Protocolo de Kyoto y la consecución de los objetivos 20/20/20 para 2020. Es decir, lograr la reducción en un $20 \%$ del consumo energético, obtener una mejora en un $20 \%$ de la eficiencia energética de los edificios y fomentar el uso de un $20 \%$ de energía procedente de fuentes renovables.

Consequently, the habitual methodology used, (15) especially indicated for the measurement of temperature and humidity, are urban transects and mobile stations, using automobiles which take climate measurements at points along their itineraries. The instrument used is generally a low inertia digital thermal hygrometer, with sensors placed on the outside of the vehicle.

The method used for our research differs from the above method, because data are taken from movable meteorological stations, carried on foot, without the use of vehicles.

References to the legal framework, (national and intertnational). Concerning the inclusion of the results of research, carried out internationally, in Urban Building Norms and/or Norms for Energy Efficiency and Saving, it can be said that the most exacting current classifications, with reference to climate zones, are very widespread, covering whole regions, cities and municipalities.

In the United States, the ASHRAE (American Society for Heating, Refrigeration , and Air-conditioning) Norms, known for being demanding and strict in energy matters, have established climate divisions by States, and within these, by cities.

In Latin America, the Argentine norms for energy, the IRAM (16) of the Argentine Institute for Norms and Certification, being the most relevant (specifically Norm IRAM 11603), does not have a rigorous climate classification for the 
En concreto, en el DB HE-0 y DB HE-1 se establecen los límites en cuanto a demanda y consumo del edificio en función de la zona climática de su localidad de ubicación y del uso previsto, poniéndose de manifiesto que diseñar la envolvente con el espesor óptimo de aislamiento es la estrategia de mayor beneficio y menor coste.

Las distintas zonas climáticas se identifican mediante una letra (de A a E), correspondiente al régimen de invierno; y un número (de 1 a 4), correspondiente a la división de verano. Cada capital de provincia tiene una zona climática asignada (Madrid: Zona D-3), la cual se va endureciendo para el resto de localidades conforme aumenta la altitud sobre el nivel del mar de su capital.

Se toman como base una serie de valores máximos y mínimos medios, de temperaturas y severidades del clima, que sirven para una zona lo bastante amplia como para englobar en su seno multitud de situaciones y casos muy diferentes entre sí. Por esta razón los recursos, constructivos y energéticos, empleados en la mayoría de los casos son muy superiores a los necesarios.

Esta forma de actuar, sobre la base de los valores climáticos globales medios, procedentes de las estaciones meteorológicas oficiales que conforman el perfil climático de la isla de calor urbana, consideramos que supone un despilfarro energético, bien sea relativo a su diseño, al cálculo de las necesidades de aislamiento o acondicionamiento de los edificios, o al confort medioambiental.

Esta investigación, con los resultados que se obtengan a largo plazo, pretende dar lugar a la elaboración de una normativa más acorde con la realidad con el fin de lograr un uso más racional del consumo de energía atribuible al proceso edificatorio como un todo.

Ejemplo de 'nanoclimas' en Madrid capital y su aplicación. Dentro de la trama urbana de Madrid capital, se eligió un trayecto que fuera suficientemente significativo y representativo, tanto por su tamaño (5.332,98 m. de longitud) como por su localización (características físicas, humanas y de tránsito, diversas).

country, although it does have some 'microclimate' considerations, and also has a general classification for a total of ten microclimates.

In Europe The French Thermal Reglament, RT-2012, is outstanding, having a classification of eight climate zones for French regions.

For Spain we must point out the CTE (Thermal Building Code), (17) the main norm framework, which sets forth technical specifications in the LOE (Law for Building Norms). (18) This includes DB, Basic Documentation, DA, for support, and HE, for energy saving. There is also a section, called "reference climates", basic documentation DB-HE, (19) updated in 2013, to be able to meet the European Norms (20) for "optimum profitability and almost zero energy consumption", applicable to all new buildings before 31st December, 2020 (2018 for public buildings).

The above updating, stemming from requirements fixed in 2006, represents an important measure for complying with the Kyoto Protocol, and the attainment of the 20/20/20 objectives for 2020 . That is to say, achieve a reduction of $20 \%$ in energy consumption, a $20 \%$ improvement in energy efficiency in buildings, and foment the use of $20 \%$ of energy from renewable energy sources.

Specifically, DB HE-O and DB HE-1 fix the limits for demand and consumption in buildings, relative to the climate zone of the location and the foreseen use, establishing that the design of the perimeter of the building with optimum levels and thickness of insulation is the best strategy for cost-effective energy savings. 

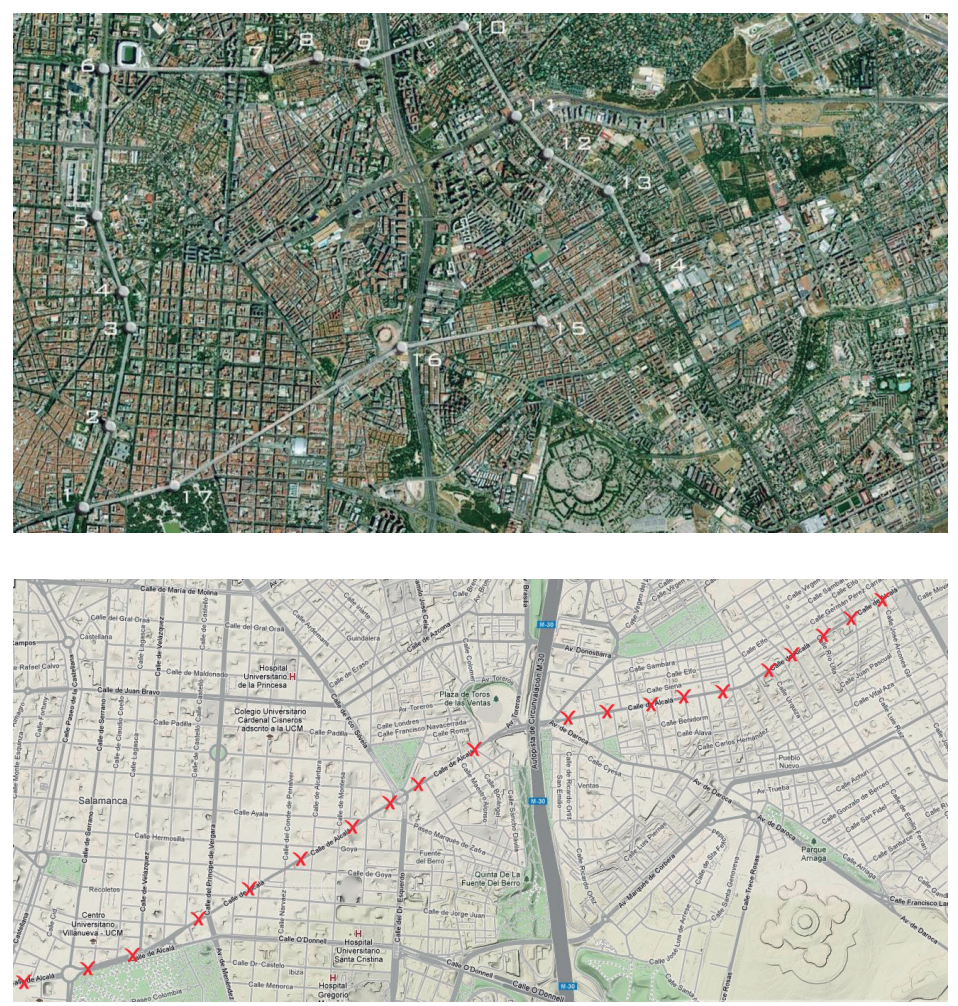

\begin{tabular}{|c|c|c|c|c|}
\hline Vértice & Latitud & Longitud & Altura & Referencia \\
\hline 1 & $40^{\circ} 25^{\prime} 08.08^{\prime \prime} \mathrm{N}$ & $3^{0} 41^{\prime} 36.32^{\prime \prime} \mathrm{O}$ & $644 \mathrm{~m}$ & Plaza de Cibeles \\
\hline 2 & $40^{\circ} 25^{\prime} 13.97^{\prime \prime} \mathrm{N}$ & $3^{0} 41^{\prime} 05.30^{\prime \prime} \mathrm{O}$ & $686 \mathrm{~m}$ & Parque de "El Retiro" \\
\hline 3 & $40^{\circ} 25^{\prime} 51.69^{\prime \prime} \mathrm{N}$ & $3^{0} 39^{\prime} 45.47^{\prime \prime} \mathrm{O}$ & $663 \mathrm{~m}$ & Plaza de Ventas \\
\hline 4 & $40^{\circ} 25^{\prime} 57.88^{\prime \prime} \mathrm{N}$ & $3^{0} 38^{\prime} 53.64^{\prime \prime} \mathrm{O}$ & $688 \mathrm{~m}$ & Plaza Quintana \\
\hline 5 & $40^{\circ} 26^{\prime} 14.65^{\prime \prime} \mathrm{N}$ & $3^{0} 38^{\prime} 16.45^{\prime \prime} \mathrm{O}$ & $694 \mathrm{~m}$ & Pza. Cruz de los Caídos \\
\hline
\end{tabular}

Fig. 1. Trayecto de estudio indicando los puntos de medición. Fuente: Google Earth
Fig. 2 Tabla de definición cartográfica de los puntos del eje del entorno de estudio. Fuente: elaboración propia.

Different energy zones are identified by means of letters, from A to E, corresponding to the Winter regime, and a number, from 1 to 4, corresponding to a Summer regime. Each provincial capital has an assigned climate zone (Madrid is Zone D-3), becoming more strict for other locations according to height above sea level of each provincial capital.

A series of maximum and minimum values are taken for temperatures, severity of the climate, covering a sufficiently ample area, to be able to include multiple and divergent contexts. For this reason the use of resources, both building and energy-wise, are far above requirements.

We consider this way of proceeding, based on average global climate values obtained from official meteorological stations, making up the profile of the urban heat-island profile, to be energy wasteful, either due to design, calculations for building insulation or environmental comfort.

The present research, with long-term harvesting of data, has the intention of developing Norms more in agreement with reality, the object being a more rational use of energy, taking into account total building processes

Example of a nano-climate in Madrid-capital, and their application. Within the urban framework of Madrid -Capital, we chose an itinerary sufficiently meaningful and representative, not only for size (5,332.98 meters in length) but for location - diverse physical, human and transit situations. 
La vía seleccionada fue el tramo de la calle Alcalá, de orientación esteoeste, comprendido entre la intersección con el Paseo de la Castellana en la Plaza de Cibeles (Punto 1) y, más al este, con la calle Arturo Soria (Punto 5). (Figs. 1 y 2)

Los puntos de medición a lo largo de dicho recorrido se establecieron a una distancia máxima de $250 \mathrm{~m}$ con el fin de poder generar una tabla de baremación con posibilidad de verificar variaciones de hasta medio grado de temperatura. Además en todos los puntos las mediciones se realizaron de forma simultánea en sus aceras pares e impares. Así se eliminaba la necesidad de tener que hacer una media ponderada de los resultados y podía observarse si había diferenciación significativa entre las fachadas en sombra y las que se hallan bajo la acción de la radiación solar.

En todos los puntos se obtuvieron los valores de temperatura, humedad relativa y presión atmosférica, siendo los dos primeros aquellos verdaderamente significativos de cara a poder cuantificar los incrementos reales de temperatura, ajenos al Sistema Integrado de Mediciones (SIM) que el Ayuntamiento de Madrid tiene instaurado en la capital pero, a nuestro juicio, a escala mucho mayor de la que planteamos en nuestra hipótesis.

Los demás datos de humedad relativa, velocidad del viento y presión barométrica sirvieron como meros indicadores por si hubiera algún error en los incrementos de temperatura existentes en el punto de medición correspondiente.

El trabajo de campo, en cuanto a mediciones físicas se refiere, respondió a una planificación anual, con un mínimo de dos mediciones semanales, en días alternos y a una misma hora solar. Para facilitar el trabajo de los becarios investigadores, en cuanto a disponibilidad se refiere, no se generaron mediciones en fin de semana (menor tráfico de usuarios de lo normal en la vía) ni en los días consecutivos con el fin de poder establecer diferencias admisibles en las mediciones realizadas.

The chosen thoroughfare was Alcalá Street, which goes from east to west, between the intersection of Paseo de la Castellana, at Cibeles roundabout (point 1)and further east, with Arturo Soria Street (point 5). (Figs. 1 and 2)

Measuring points along the said itinerary are placed at a maximum distance of 250 meters, with the object of being able to draw up a chart with variations of up to $5^{\circ} \mathrm{C}$. Moreover, measurements were carried out simultaneously on both sides of the street. In this way we eliminated the need to average out the results, and were able to observe a significant temperature variation between buildings on the sunny side and the shady side of the street.

At all points we obtained values for temperature, relative humidity and air pressure, the first two being really meaningful for the quantification of real temperature increases, ignoring the measurements of the Madrid City system, called the Integrated Measurement System (SIM-Sistema Integrado de Mediciones) established in Madrid by the City Council. Said city measurement system is, in our opinion, at a scale too large for our purposes.

Other data for relative humidity, wind speed, and barometric pressure were used merely to verify the exactitude of our temperature measurements, in case there may have been some error in our equipment at a specific point of measurement.

The field work, as far as physical measurements are concerned, was based on a yearly planning, with a minimum of two measurements weekly, on alternate days, and at the same solar hour. To facilitate work of the trainee researchers, 
La metodología utilizada para llevar a cabo el trabajo de campo consistió en la toma de datos directa, a pie de calle, en los puntos seleccionados, con estaciones meteorológicas portátiles KRESTEL 4000. Las temperaturas se tomaron con incrementos de $\pm 0,5^{\circ} \mathrm{C}$, en días constantes, a horas constantes e intervalos constantes dentro del plan de trabajo. La referencia en longitud fueron los portales de acceso (situados en planimetría en cota y posición) separados 20 números de la calle. Cuando esta referencia no fue posible, se tomaron medidas cada $200 \mathrm{~m}$ aproximadamente.

Se pudieron obtener las mediciones de los distintos parámetros especificados, a tiempo real y de forma sistemática y se generaron así tablas de medición para cada mes del año en cada punto de estudio con el fin de establecer medias mensuales ponderadas en los períodos de simulación más desfavorables (invierno y verano).

Posteriormente, se analizaron todos aquellos aspectos de la morfología urbana que pudieran afectar a las diferencias de temperaturas registradas, para tenerlos en cuenta a la hora de establecer cualquier tipo de conclusión al respecto: vegetación o ausencia de ésta, tipo de pavimento, grado de tráfico de la calle, anchura, tránsito de usuarios, colores de acabado de los materiales de las fachadas y mobiliario urbano (incidentes en el albedo).

En este sentido se pudo comprobar la influencia local del parque del Retiro así como de las áreas arboladas o con vegetación en los puntos de medición que se encontraban próximos, pues se observó la reducción de la temperatura y el incremento de la humedad relativa.

También se constataron diferencias en cuanto a las condiciones climáticas de los distintos puntos de medición dentro de una misma acera de la calle Alcalá, (tanto en sus números pares como impares), a una misma hora, lo que nos permite suponer un indicio de la variabilidad de las condiciones climáticas en función de los condicionantes locales de ubicación, siendo notables las diferencias entre las temperaturas máximas y mínimas de hasta $6^{\circ} \mathrm{C}$ en todo el trayecto. (Fig. 3)

concerning their availability, no measurements were done on weekends -less traffic than during weekdays- nor were measurements made on consecutive days, with the object of being able to have admissible data.

The methodology was to take direct measurements, on the street, at selected points, using portable meteorological stations KRESTEL 4000. Temperatures were taken at $5^{\circ} \mathrm{C}$ approx. on uniform days, uniform hours and uniform intervals within the working plan. References for measurement spacing were based on doorways at every 20 street numbers. When this was not possible, spacing was approximately every 200 meters.

We were able to obtain measurements at the different specified parameters, in real time, systematically, and measurement charts were drawn up for each month of the year at each measuring point, in order to be able to average-out monthly data at the most unfavourable times, winter and summer.

Later, all aspects of urban morphology were analyzed, to see if they affected the registered measurements, to be taken into account when drawing up conclusions: vegetation or lack thereof, type of pavement, degree of traffic, road width, pedestrian traffic, colours of buildings and material used on façades, and urban furnishings such as benches.

With respect to the above, we could verify the effects of the Retiro Park and other tree-lined areas or vegetation at nearby measuring points, observing lower temperatures and higher degrees of relative humidity. 


\begin{tabular}{|c|c|c|c|c|c|}
\hline \multicolumn{2}{|c|}{ TRABAJO DE CAMPO } & \multicolumn{3}{|c|}{ TOMA DE DAIOS CUMAIOLOGICOS C/ ALCALÁ - MADRID } & \multirow{2}{*}{$\begin{array}{r}\text { A01 } \\
3^{\circ} 38^{\prime} 57^{\prime \prime} \mathrm{O}\end{array}$} \\
\hline MES & SEPIIEMBRE 2013 & & & $40^{\circ} 25^{\prime} 59^{\prime \prime}$ & \\
\hline DIA & TEMPERATURA $\left({ }^{\circ} \mathrm{C}\right)$ & HUMEDAD RELATIVA (\%) & VELOCIDAD VIENTO $(\mathrm{m} / \mathrm{s})$ & PRESIÓN ATMOSF. (KPa) & MED TEMP H० \\
\hline 3 & 23.80 & 48,20 & 0,80 & 93.98 & 20,50 \\
\hline 5 & 24,10 & 49.70 & 0.70 & 93.96 & 20,50 \\
\hline 10 & 22,90 & 44,10 & 0,40 & 94,40 & 20,50 \\
\hline 12 & 17.80 & 48.70 & 0,50 & 94,39 & 20,50 \\
\hline 17 & 23,60 & 46.00 & 0.00 & 93.52 & 20,50 \\
\hline 19 & 24,50 & 38,10 & 0,00 & 93,87 & 20,50 \\
\hline 24 & 25,10 & 39.60 & 0,30 & 93.61 & 20,50 \\
\hline 26 & 24,30 & 39,80 & 0.00 & 93.56 & 20,50 \\
\hline MEDIA & 23,26 & 44,28 & 0,34 & 93,91 & 20,50 \\
\hline COTA & 687,77 & & & & \\
\hline
\end{tabular}

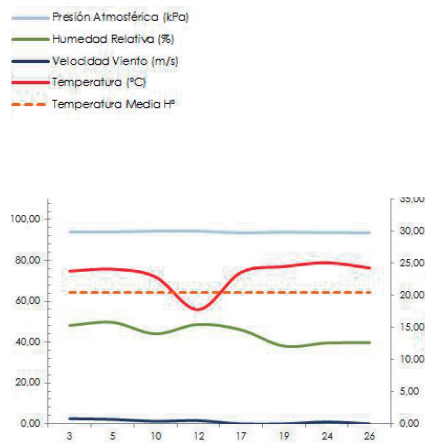

\begin{tabular}{|c|c|c|c|c|c|}
\hline \multicolumn{5}{|c|}{ RESUMEN TEMPERATURAS MEDIAS VERANO C/ ALCALÁ - MADRID } & R01a \\
\hline \multicolumn{4}{|c|}{ VERANO } & \multicolumn{2}{|c|}{21 de junio al 20 septiembre } \\
\hline DIA & Tm JUNIO & Tm JULIO & Tm AGOSTO & Tm SEPTIEMBRE & Tm TOTAL \\
\hline Al & 21,35 & 25,34 & 23.26 & 22,78 & 23,18 \\
\hline A2 & 19,30 & 23,72 & 24,76 & 22,78 & 22,64 \\
\hline B1 & 21,06 & 25,61 & 23,64 & 22,93 & 23,31 \\
\hline B2 & 19.50 & 24,74 & 24,21 & 22,00 & 22,61 \\
\hline $\mathrm{Cl}$ & 21,13 & 27.50 & 23,06 & 21.97 & 23,41 \\
\hline $\mathrm{C} 2$ & 21,80 & 26,34 & 23,83 & 22,28 & 23.56 \\
\hline$\Delta \mathrm{I}$ & 2,50 & 3,78 & 1,70 & 0,96 & 0,95 \\
\hline
\end{tabular}

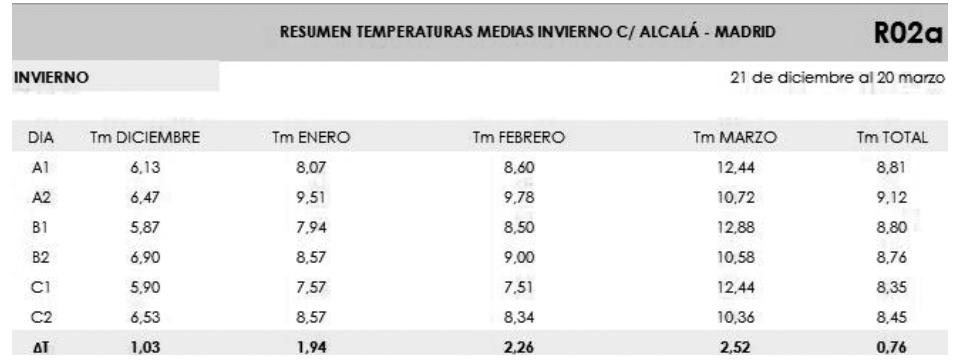

Fig. 3. Trabajo de campo. Fichas de datos climatológicos obtenidos (mediciones e incrementos de temperatura detectados). Fuente elaboración propia.

We were also able to observe climate variations at different measuring points on the same pavement side of the street, at the same hour, which allows us to suppose variations in climate relative to location, giving differences of up to $6^{\circ} \mathrm{C}$ on all the itinerary. (Fig. 3 )

We therefore had a solid basis for our research, in view of proposing new concepts for energy savings in the framework of the European Directives.

Chosing an architectural simulation mode. Within the research, as required by the planned objectives, we had different urban and building typologies to take into account, and the use of different building materials. That is to say, various architectural possibilities. Despite the apparent singularity of some buildings, any of them could serve as a reference for our study, because the essential criteria is the building's location, said location made extensive to virtual locations, in order to be able to simulate climate situations in our field work and thus quantify different energy loads -consequently different energy requirements- which would be generated by new external conditions, and be able to compare influences, both with energy losses and gains within different climate values.

In view of the above considerations, we decided to adopt an Alcalá Street building as the typology of a closed residential concept, with a main façade, an inner yard, with two lateral bays. The residential block chosen dates from 1955, an important year in Madrid's urban history, which marked the beginning of council housing such as Hortaleza, Canillas. Our standard is therefore a building located at Calle Alcalá number 3408. (Fig. 4) 
Se ha dispuesto, pues, una base sólida sobre la que apoyar la investigación para proponer un nuevo concepto de entender el ahorro energético tal y como lo plantean las directrices europeas en esta materia.

Elección del modelo arquitectónico a simular. Dentro del trayecto de estudio, como era requisito para su elección, se contaba con distintas tipologías urbanas y edificatorias, construidas con diferentes materiales. Es decir, con varias posibilidades. Sin embargo, a pesar de la aparente singularidad de los edificios, cualquiera de ellos podía servir como referencia para nuestro objetivo, pues lo esencial sería su posicionamiento, además de en su ubicación real, en otras localizaciones de solar virtuales, con el fin de poder simular las condiciones climáticas medidas en el trabajo de campo y cuantificar las diferentes cargas térmicas (en consecuencia, las diferentes demandas de energía) que se generarían a partir de las nuevas condiciones exteriores y comparar la influencia, tanto en las pérdidas y ganancias, como en las cargas térmicas de los diferentes valores climáticos.

Tras esta serie de consideraciones, se decide adoptar como modelo de bloque de vivienda uno a priori encuadrado en el tiempo en el ecuador de la historia urbana del eje de la calle Alcalá, el cual responde a una tipología arquitectónica de manzana cerrada, de edificio entre medianeras, con una fachada principal y un patio interior de servicio con dos crujías laterales que albergan las piezas de vivienda. El año de construcción del bloque de viviendas elegido es el de 1955, año determinante en la historia urbanística de Madrid que coincide con la creación de los barrios de vivienda protegida y poblados dirigidos en la capital (Hortaleza, Canillas...).

Nuestro modelo de estudio estándar ha sido, pues, un edificio de referencia de igual tipología al situado en la calle Alcalá en su número 308. (Fig. 4)
Fig. 4. Planimetría y vistas del edificio de referencia (C/Alcalá, 308). Fuente: elaboración propia.

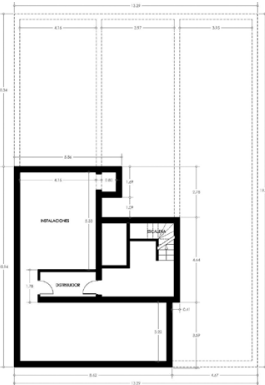

Planta sótano.

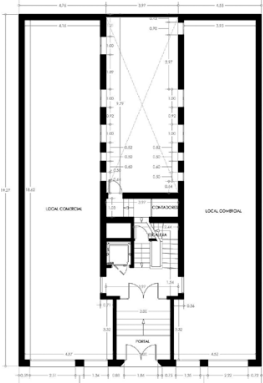

Planta baja.

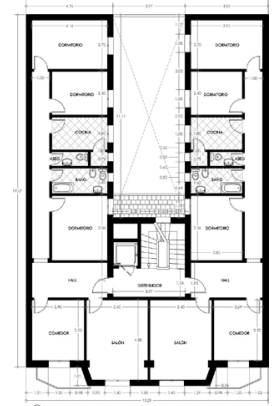

Planta tipo.

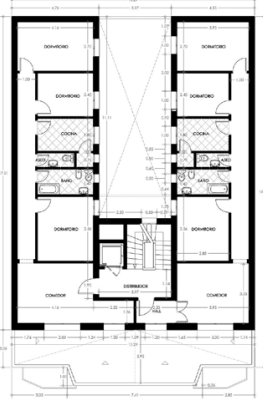

Planta ático.

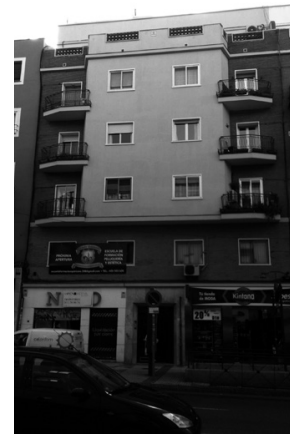

Fachada principal.

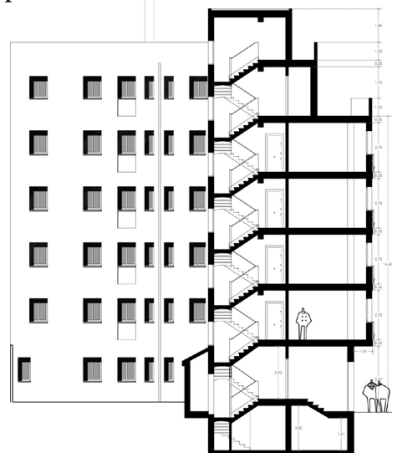

Sección transversal por escalera.

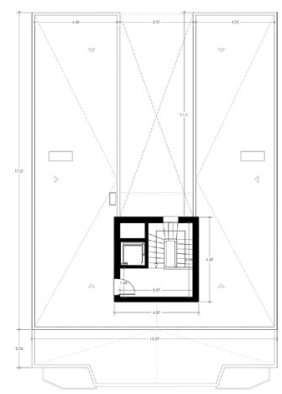

Planta cubierta.

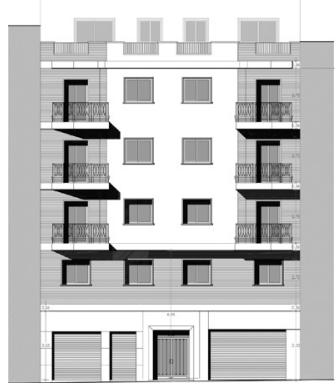

Alzado principal. C/Alcalá. 
Método de cálculo. Una vez establecida la base de datos climáticos a emplear, utilizando programas de cálculo probados y validados (tales como el Energy Plus de simulación energética), se ha simulado el citado modelo virtual estándar, para calcular sus diferentes demandas de calefacción y refrigeración (en invierno y en verano respectivamente), y de ventilación (en ambas estaciones) atendiendo a distintas posiciones de éste dentro del entorno urbano elegido. Es decir, atendiendo a las demandas generadas por la edificación de referencia en cada una de las aceras de las localizaciones A, B y C del trayecto seleccionado de la C/ Alcalá. (Fig. 5)

Para generar las situaciones virtuales empleadas para el mismo modelo en distintos entornos se consideraron los incrementos (positivos o negativos), no los valores medios de la temperatura, dado que se pudo observar que, dentro de un mismo entorno urbano, a escala incluso de barrio o manzana, aparecen variaciones de temperatura (positivas o negativas) respecto al valor medio de la temperatura general de la ciudad, que es la que se emplea en cualquier cálculo energético (siendo ese valor medio de hasta $3^{\circ} \mathrm{C}$ de variación respecto el referido a la estación meteorológica más cercana, en este caso, Retiro). De esta forma, la escala de medición era siempre la misma.

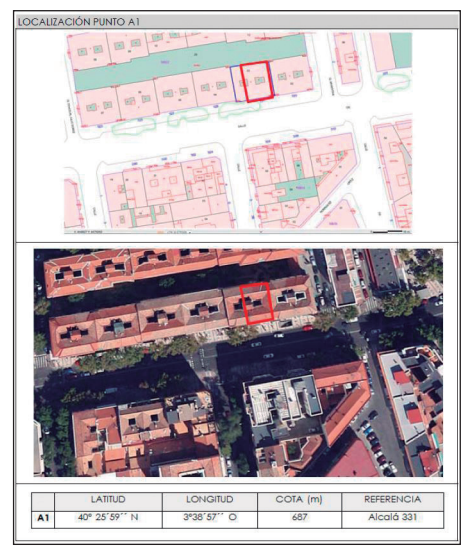

Localización pto. A1

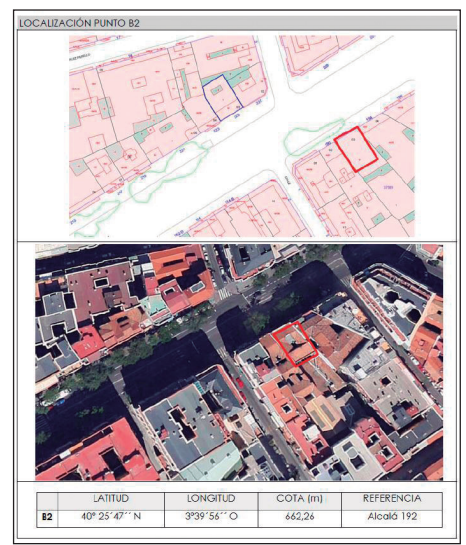

Localización pto. B2

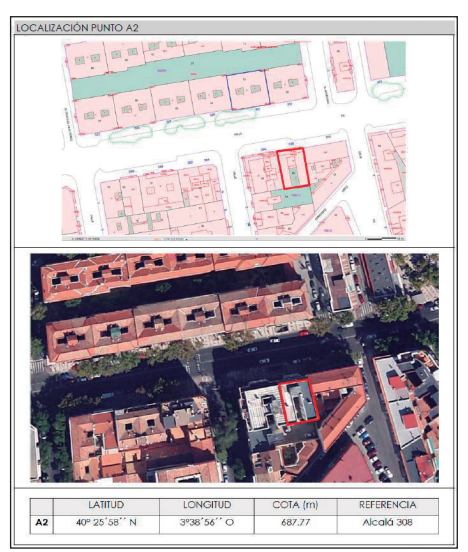

Localización pto. A2

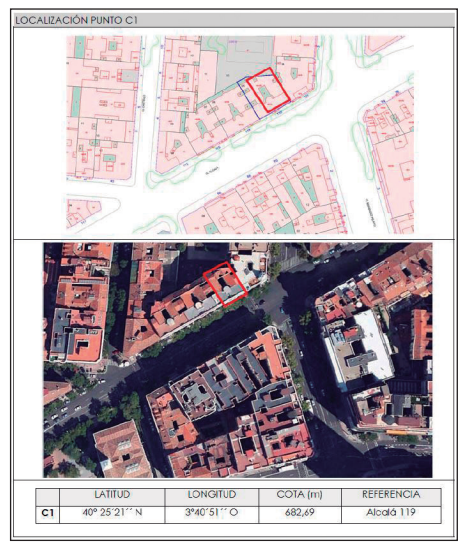

Localización pto. C1
Fig. 5. Puntos de situación para simulación del edificio de referencia a lo largo del eje de estudio.

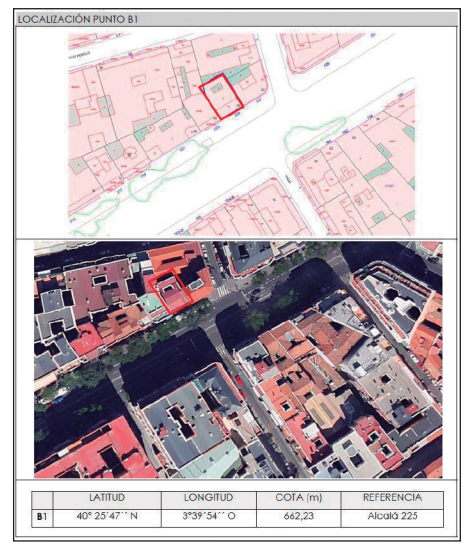

Localización pto. B1

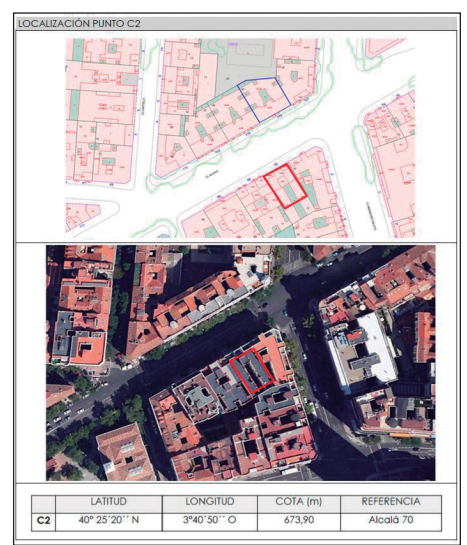

Localización pto. C2 
La diferencia entre los resultados obtenidos (Figs. 6 y 7) permitió cuantificar el porcentaje de ahorro que podríamos proponer, atendiendo a esta nueva base de datos climatológicos ('nanoclimas urbanos'), respecto a los valores de referencia actualmente establecidos por la normativa vigente y simulados conforme a la base de datos climatológicos actual de la Agencia Estatal de Meteorología (AEMET).

Así pues, toda diferencia de energía ha sido entendida como un ahorro de la misma puesto que el diseño a aplicar en la arquitectura que responda a las necesidades de esa parcela de trama urbana se verá afectado por estos nuevos valores de cálculo, mucho más cercanos a la realidad física existente.

Conclusiones. Ante todo es preciso señalar que la evaluación de los resultados obtenidos es sintomática y los modelos, provisionales, pues un estudio exhaustivo requeriría varios años (de al menos un periodo 'clino') y el estudio que se presenta se basa en las mediciones efectuadas durante un solo año.

Sin embargo los datos climatológicos registrados sí permiten constatar diferencias o incrementos significativos entre ellos, que apuntan a una especificidad ('nanoclimas urbanos') que difiere de los datos del Instituto Me-
Fig. 6. Tabla de resultados de cargas térmicas para las distintas localizaciones. Fuente: elaboración propia.

\begin{tabular}{|c|c|c|c|c|c|c|c|c|c|c|c|c|}
\hline \multirow[b]{2}{*}{ CARGAS (W) } & \multicolumn{2}{|c|}{ Al } & \multicolumn{2}{|c|}{ A2 } & \multicolumn{2}{|c|}{ B1 } & \multicolumn{2}{|c|}{ B2 } & \multicolumn{2}{|c|}{$\mathrm{Cl}$} & \multicolumn{2}{|c|}{ C2 } \\
\hline & REFRIG. & CALEF. & REFRIG. & CALEF. & REFRIG. & CALEF. & REFRIG. & CALEF. & REFRIG. & CALEF. & REFRIG. & CALEF. \\
\hline PLANTA SÓTANO & 0.00 & 0.00 & 0.00 & 0.00 & 0.00 & 0.00 & 0.00 & 0.00 & 0.00 & 0.00 & 0.00 & 0.00 \\
\hline PLANIA BAJA & 0.00 & 0.00 & 0.00 & 0.00 & 0.00 & 0.00 & 0.00 & 0.00 & 0.00 & 0.00 & $0 . \infty$ & 0.00 \\
\hline PLANTA I & 5.955 .11 & 14.469 .44 & 3.178 .89 & 8.244 .09 & 5.004 .40 & 13.380 .81 & 4.840 .48 & 12.762 .01 & 6.088 .36 & 13.208 .16 & 5.709 .85 & 12.889 .86 \\
\hline PLANTA 2 & 6.451 .20 & 13.460 .45 & 3.671 .72 & 11.274 .12 & 5.393 .65 & 12.478 .11 & 5.290 .54 & 11.922 .78 & 6.058 .17 & 12.322 .69 & 6.160 .74 & 12.037 .90 \\
\hline PLANTA 3 & $6.762,72$ & 11.639 .75 & 3.847 .70 & 9.907 .80 & 5.543 .17 & 10.847 .22 & 5.399 .76 & 9.772 .10 & 6.618 .13 & 10.722 .94 & 5.830 .98 & 10.510 .78 \\
\hline PLANTA 4 & 7.269 .86 & 14.364 .72 & 3.392 .88 & 11.958 .41 & $6.232,06$ & 13.289 .02 & 6.047 .90 & 12.674 .35 & $7.528,00$ & 13.118 .32 & 7.149 .56 & 12.800 .74 \\
\hline PLANIA AIICO & 8.197 .99 & 16.495 .02 & 4.907 .11 & 13.508 .96 & 7.024 .21 & $15.172,34$ & 6.090 .68 & 14.398 .54 & 8.169 .39 & 14.961 .46 & 6.712 .42 & 14.554 .46 \\
\hline IOTAL EDIFCIO & 34636,88 & 70429,38 & 18998,3 & 54893,38 & 29197,49 & 65167,5 & 27669,36 & 61529,78 & 34462,05 & 64333,57 & 31563,55 & 62793,74 \\
\hline
\end{tabular}

Calculation method. Having fixed the climate data, using well-proven programs such as Energy Plus for energy simulation, we projected said standard virtual model in order to calculate different heating and cooling requirements (both for winter and summer), and ventilation (both seasons), considering various positions within the urban area chosen. That is to say, following the demands generated by the reference building on one of the pavements in locations $\mathrm{A}, \mathrm{B}$ and $\mathrm{C}$ of the itinerary chosen on Alcalá street. (Fig. 5)

To generate a virtual situation, using the same model in different environments, we took into account variations (positive and negative) and not average temperatures, having observed that there are changes, both positive and negative, with respect to average city temperatures. Said averages are used for any energy calculation (varying up to 3 degrees Celsius with respect to the nearest measuring station, in our case, the Retiro Park). In this way, the measuring scale was always uniform.

Differences in obtained results (Fig. 6) allowed us to quantify percentages of savings, and using this new data (urban nano-climates), with respect to current norms based on data given by the State Meteorological Agency (AEMET), we have been able to present herewith our proposals.

Therefore, all difference in energy levels have been taken as representing energy savings based on new calculations derived from our calculations, being much closer to current urban realities. 


\begin{tabular}{|c|c|c|c|c|}
\hline \multicolumn{5}{|c|}{ COMPARACIÓN ENERGÉTICA DE PUNIOS DE SIMULACIÓN } \\
\hline \multirow[b]{2}{*}{ CARGAS (W) } & \multicolumn{2}{|c|}{$\Delta \mathbf{P}$} & \multicolumn{2}{|c|}{$\%$} \\
\hline & REFRIG. & CALEF. & REFRIG. & CALEF. \\
\hline PLANTA SÓTANO & 0.00 & 0.00 & 0.00 & 0.00 \\
\hline PLANIA BAJA & 0.00 & 0.00 & 0.00 & 0.00 \\
\hline PLANTA I & 2.909 .47 & 6.225 .35 & 1.92 & 1.76 \\
\hline PLANTA 2 & 2.779 .48 & $2.186,33$ & 1.76 & 1.19 \\
\hline PLANTA 3 & 2.915 .02 & 1.867 .65 & 1.76 & 1.19 \\
\hline PLANIA 4 & 4.135 .12 & 2.406 .31 & 2,22 & 1.20 \\
\hline PLANTA ATICO & 3.290 .88 & 2.986 .06 & 1.67 & 1.22 \\
\hline TOTAL EDIFCIO & $15.638,58$ & $15.536,00$ & 9,32 & 6,56 \\
\hline
\end{tabular}

teorológico (base Retiro) y del Sistema Integrado de Mediciones (SIM) del Ayuntamiento de Madrid. Constatamos la existencia de 'nanoclimas urbanos' dentro de un clima clasificado como D3 en el vigente CTE.

Debido a la influencia de la serie de factores aquí estudiados (nueva base de datos climatológicos, orientación, soleamiento, sombras arrojadas...) se puede deducir que, dependiendo de la ubicación, en un mismo entorno urbano del edificio tomado como referencia, es posible obtener hasta un $9,32 \%$ de diferencia en cuanto a las cargas de refrigeración se refiere y un $6,56 \%$ respecto a las de calefacción.

La diferencia de hasta el 10\% en la demanda de energía de cada vivienda supondría, contemplada a escala urbana (edificio-manzana-distrito-ciudad), un ahorro de tal magnitud que resulta muy difícil de evaluar en términos económicos.

La optimización del ahorro global que se puede conseguir mediante la disminución de la escala de medida de las condiciones climáticas permitirá
Fig. 7. Tabla de resultados de incrementos de energía para las distintas localizaciones. Fuente: elaboración propia.

Conclusions. It is necessary to point out that the obtained results are only provisional, since a full study would require several years, and the present study was only carried out over one year.

Nevertheless, registered data allow the verification of urban temperatures which differ notably from Municipal measurements and the SIM (Integrated Measurement Systems) of the city of Madrid. We have verified the existence of urban nano-climates within the climate classified as D3, current CTE.

Due to the influence of factors here set forth (new climate data, orientation, sun, shade, etc.) we can deduce that, varying the urban location of the reference building, different cooling loads $(9.32 \%)$ and heating loads (6.56\%) can be obtained.

Differences of up to10\% in energy requirements for each residence would mean, at an urban scale (building, block, district, city) such a savings that the economic impact would be difficult to evaluate.

Global energy savings, obtained through a reduction of the measuring scale for climatic conditions, would allow not only important savings of resources and means, both in edification and energy, but also systems for fuel distribution, both solid and liquid, without this affecting levels of comfort. This would also reduce the production of greenhouse gases, and would fight climate change. 
lograr no sólo un importante ahorro de los recursos y los medios, tanto constructivos como energéticos, sino también de la distribución y transporte de los combustibles sólidos o líquidos, sin merma de las condiciones de confort; favoreciendo, a su vez, la reducción de la emisión de gases de efecto invernadero y la atenuación del cambio climático.

Es por esta razón por la que abogaremos siempre por un giro institucional y político hacia este camino a seguir. Sólo redefiniendo el marco normativo existente podremos ser eficientes en la arquitectura sin hacer arquitectura.

La toma de datos climatológicos efectuada ha servido para mostrar las dos hipótesis de partida. Por un lado, la existencia de 'nanoclimas urbanos' y, por el otro, el ahorro en términos energéticos -y lo que podría suponer su aplicación- frente a los valores máximos y mínimos medios proporcionados por la normativa oficial vigente.

El conocimiento a fondo de los 'nanoclimas urbanos' en Madrid capital, es decir, su identificación y cuantificación real, de manera inequívoca, será un objetivo a largo plazo, con el fin de que éstos puedan servir de base para elaborar la futura normativa oficial y emplearse como un modelo de referencia trasladable a cualquier otra ciudad.

Esta investigación sólo pretende poner de manifiesto, sacar a la luz, su existencia y mostrar la gran influencia que podrían tener en la disminución del gasto energético global urbano.

For these reasons we propose political and institutional changes. Only with a redefinition of current Norms, will we be able to alter the architectural landscape.

The harvesting of data has allowed us to set forth two hypothesis: on the one hand, the existence of urban nanoclimates, and on the other hand, energy savings, with maximums and minimums with respect to current Official Norms.

A full knowledge of Madrid's urban nano-climates implies their identification and quantification, being a long-term objective to be able to serve as a basis for reference models applicable to any city.

The object of the present study has been to bring to light the existence of urban nano-climates, and show the great influence they could have on the reduction of global urban energy expenditure. 


\section{NOTAS}

1. Los primeros estudios y preocupaciones sobre el clima urbano se remontan a la Grecia Clásica. El médico Hipócrates (s.V a.C) en su obra denominada De los aires, de las aguas y de los lugares ya relaciona el aire distinto de las ciudades con la salud humana.

2. Proyecto de Investigación NANOCLIMA, ('Nanoclimas urbanos en Madrid capital: optimización del ahorro energético'), que se está desarrollando por un equipo perteneciente a la Escuela Superior de Arquitectura y Tecnología (ESAyT), con fondos de la Universidad Camilo José Cela (UCJC).

3. HOWARD, Luke. The climate of London. Londres: Longman, 1818. 2 vols. 4. RENOU, Emilien. 'Différences de témperature entre la ville et la campagne', en Annuaire Socc. Met. France, n. 3, 1868. 83-97 pp. 5. Destacamos: CHANDLER, Tony J. The Climate of London. Londres: Hutchinson \& Co., 1965.

6. 'Captado' no implica que se mida la emisión real ya que debido a la contaminación, la nubosidad, las partículas en suspensión, etc., en cada momento la recepción mide un valor 'enmascarado' por todos estos agentes. 7. LÓPEZ GÓMEZ, Antonio; LÓPEZ GÓMEZ, J.; FERNÁNDEZ GARCÍA, F.; MORENO JIMÉNEZ, A. El clima urbano. Teledetección de la isla de calor en Madrid. Madrid: Ministerio de Obras Públicas y Transportes, Secretaría de Estado para las políticas del Agua y el Medio Ambiente, 1993. 8. Entre otros, destacamos: LÓPEZ GÓMEZ, Antonio; LÓPEZ GÓMEZ, Julia; FERNÁNDEZ GARCÍA, Felipe; ARROYO LLERA, Fernando. $E l$ clima urbano de Madrid: la isla de calor. Madrid: CSIC, 1991. 9. CARRERAS, Carles; MARÍN, Mercedes; MARTÍN VIDE, Javier; MORENO, $M^{\text {a }}$ del Carmen; SABÍ, Joan. 'Modificaciones térmicas en las ciudades. Avance sobre la isla de calor en Barcelona'. Documents d'análisi Geográfica, n. 17. 1990. 51-77 pp. MORENO, Ma del Carmen. Estudio del clima urbano de Barcelona: la isla de calor. Barcelona: Oikos-Tau, 1993. 10. CUADRAT PRATS, José Ma; DE LA RIVA, Juan; LÓPEZ MARTÍN, Fernando; MARTÍ EZPELETA, Alberto. 'Ciudad y Medio Ambiente: la isla de calor de Teruel. Geographicalia, n. 30. 1993. 113-123 pp.

11. MTNEZ. MTNEZ., Jorge. 'Estudio de la isla de calor de la ciudad de Alicante’. Investigaciones Geográficas, n. 62. 2014. 83-99 pp.

12. En general, con la expresión 'microclima' se suele hacer referencia a que dentro del clima de un área geográfica existen enclaves (un valle, una zona montañosa, una ciudad...) que presentan valores generales de temperatura, humedad relativa, vientos, etc., que son distintos de los del entorno. Es decir, un clima con características propias, que dependiendo del anterior, es distinto de él.

13. OKE, Tim R. 'City size and the urban heat island'. Atmospheric Environment, n. 7. 1973. $769-779 \mathrm{pp}$.

14. SERRA PARDO, Juan Antonio. 'Estudio de la isla de calor de la ciudad de Ibiza'. Investigaciones Geográficas, n. 44. 2007. 55-73 pp.

15. Metodología iniciada en 1927 por Schmidt en Viena y por Peppler en Karlsruhe.

16. Originalmente denominado Instituto Argentino de Racionalización de Materiales. La regulación energética en edificios se da mediante las Normas IRAM 11604 y 11659-2. Ambas establecen el valor admisible de pérdidas de calor de un edificio en función de utilizar varios indicadores. 17. CTE regulado por el Real Decreto 314/2006, de 17 de marzo.

18. LOE: Ley 38/1999, de 5 de noviembre.

19. DB HE de Ahorro de Energía revisado mediante la Orden FOM/1635/2013, de 10 de septiembre.

20. Directiva 2010/31/UE, de 19 de mayo, relativa a la eficiencia energética de los edificios (refundición).
NOTES

1. The first studies about urban climates date from Classical Greece.

The physician Hypocrates 5 th century BC in his work called Air, Waters and Places links city air with human health.

2. Nano-Climate Research Project ('Nanoclimas urbanos en Madrid capital: optimización del ahorro energético'), currrently being carried out by a team from the Escuela Superior de Arquitectura y Tecnología (ESAyT), funded by the Camilo Jose Cela University (UCJC).

3. HOWARD, Luke. The climate of London. London: Longman, 1818. 2 vols. 4. RENOU, Emilien. 'Différences de témperature entre la ville et la campagne', en Annuaire Socc. Met. France, n. 3, 1868. 83-97 pp.

5. Destacamos: CHANDLER, Tony J. The Climate of London. Londres: Hutchinson \& Co., 1965.

6. 'Captured' heat does not mean that real heat is measured, since pollution, cloudiness, air particles, etc., give altered results.

7. LÓPEZ GÓMEZ, Antonio; LÓPEZ GÓMEZ, J.; FERNÁNDEZ

GARCÍA, F.; MORENO JIMÉNEZ, A. El clima urbano. Teledetección de la isla de calor en Madrid. Madrid: Ministerio de Obras Públicas y Transportes, Secretaría de Estado para las políticas del Agua y el Medio Ambiente, 1993.

8. LÓPEZ GÓMEZ, Antonio; LÓPEZ GÓMEZ, Julia; FERNÁNDEZ GARCÍA, Felipe; ARROYO LLERA, Fernando. El clima urbano de Madrid: la isla de calor. Madrid: CSIC, 1991.

9. CARRERAS, Carles; MARÍN, Mercedes; MARTÍN VIDE, Javier; MORENO, $M^{\text {a }}$ del Carmen; SABÍ, Joan. 'Modificaciones térmicas en las ciudades. Avance sobre la isla de calor en Barcelona'. Documents d'análisi Geográfica, n. 17. 1990. 51-77 pp. MORENO, Ma del Carmen. Estudio del clima urbano de Barcelona: la isla de calor. Barcelona: Oikos-Tau, 1993.

10. CUADRAT PRATS, José Ma; DE LA RIVA, Juan; LÓPEZ MARTÍN, Fernando; MARTÍ EZPELETA, Alberto. 'Ciudad y Medio Ambiente: la isla de calor de Teruel'. Geographicalia, n. 30. 1993. 113-123 pp.

11. MTNEZ. MTNEZ., Jorge. 'Estudio de la isla de calor de la ciudad de Alicante'. Investigaciones Geográficas, n. 62. 2014. 83-99 pp.

12. In general, the expression 'Microclimate' usually refers to the existence of enclaves in geographical areas (a valley, mountains, a city) which have temperatures, levels of humidity, winds, etc different from the surrounding area i.e., climates having their own characteristics, although dependant on other areas.

13. OKE, Tim R. 'City size and the urban heat island'. Atmospheric Environment, n. 7. 1973. 769-779 pp.

14. SERRA PARDO, Juan Antonio. 'Estudio de la isla de calor de la ciudad de Ibiza'. Investigaciones Geográficas, n. 44. 2007. 55-73 pp.

15. Methodology started in 1927 by Schmidt in Vienna, and by Peppler in Karlsruhe.

16. Originally called 'Instituto Argentino de Racionalización de Materiales. Energy regulation in buildings is through Norms IRAM 11604 and 11659-2.Both fix allowable levels of heat loss in buildings, using specific indicators.

17. CTE is regulated by Royal Degree 314/2006, March 17 th.

18. LOE: Law 38/1999, September 5th.

19. DB HE for Energy Saving, revised through Order FROM/1635/2013, September 10th.

20. Directive 2010/31/UE, May 19th, relative to energy efficiency in buildings (modification). 